\title{
PERLINDUNGAN HUKUM TERHADAP ISTRI (KORBAN KEKERASAN DALAM RUMAH TANGGA)
}

\author{
OLEH : \\ I.A. INDAH SUKMA ANGANDARI.,SH., MH
Fakultas Hukum Universitas Mahendradatta, Jalan Ken Arok Nomor 12
Denpasar

\begin{abstract}
ABSTRAK, Keutuhan dan kerukunan rumah tangga dapat terganggu jika kualitas dan pengendalian diri tidak dapat dikontrol, yang pada akhirnya dapat mengakibatkan terjadinya kekerasan dalam rumah tangga. Kekerasan dalam Rumah Tangga adalah setiap perbuatan terhadap seseorang terutama istri, yang berakibat timbulnya kesengsaraan atau penderitaan secara fisik, seksual, psikologis. Untuk mencegah, melindungi istri sebagai korban, dan menindak pelaku kekerasan dalam rumah tangga pada tanggal 22 September 2004, telah disahkan berlakunya Undang-undang Nomor 23 Tahun 2004 tentang Penghapusan Kekerasan Dalam Rumah Tangga (PKDRT), yang terdiri atas 10 Bab dan 56 Pasal. Undang-undang tersebut diharapkan dapat memberikan perlindungan hukum bagi anggota dalam rumah tangga, khususnya perempuan, yang paling banyak menjadi korban kekerasan dalam rumah tangga.
\end{abstract}

\section{Kata kunci : Perlindungan, kekerasan, Istri}

ABSTRACT, Wholeness and harmony of the household may be disrupted if the quality and self-control can not be controlled, which can ultimately lead to the occurrence of domestic violence. Domestic Violence is any action against someone, especially his wife, which resulted in misery or suffering physical, sexual, psychological. To prevent, protect the wife as a victim, and prosecution of domestic violence on September 22, 2004, was approved the introduction of Law Number 23 Year 2004 on the Elimination of Domestic Violence (PKDRT), which consists of 10 Chapters and 56 Articles. The law is expected to provide legal protection for members in the household, particularly women, the most victimsodomestiviolence.

Key words: Protection, violence, wife

\section{A. Latar Belakang}

Selama ini rumah tangga dianggap sebagai tempat yang aman karena seluruh anggota keluarga merasa damai dan terlindungi. Keutuhan dan kerukunan rumah tangga yang bahagia, aman, tenteram, dan damai merupakan dambaan setiap orang dalam rumah tangga. Untuk mewujudkan keutuhan dan kerukunan tersebut, sangat tergantung pada setiap orang dalam lingkup rumah tangga, terutama kadar kualitas perilaku dan pengendalian diri setiap orang dalam lingkup rumah tangga tersebut. Keutuhan dan kerukunan rumah tangga dapat terganggu jika kualitas dan pengendalian diri tidak dapat dikontrol, yang pada akhirnya dapat mengakibatkan terjadinya kekerasan dalam rumah tangga sehingga timbul ketidakamanan atau ketidakadilan terhadap orang yang berada dalam lingkup rumah tangga tersebut.

Kekerasan dalam rumah tangga (KDRT) sebagai salah satu jenis kekerasan yang berbasis gender dari waktu ke waktu terus meningkat. Hal ini pertama dilatarbelakangi oleh budaya patriarki yang terus langgeng, 
kesetaraan gender yang belum nampak serta nilai budaya masyarakat yang selalu ingin hidup harmonis sehingga cenderung selalu menyalahkan perempuan.

Tindak kekerasan di dalam rumah tangga (domestic violence) merupakan jenis kejahatan yang kurang mendapatkan perhatian dan jangkauan hukum. Tindak kekerasan di dalam rumah tangga pada umumnya melibatkan pelaku dan korban diantara anggota keluarga di dalam rumah tangga, sedangkan bentuk tindak kekerasan bisa berupa kekerasan fisik dan kekerasan verbal (ancaman kekerasan). Pelaku dan korban tindak kekerasan didalam rumah tangga bisa menimpa siapa saja, tidak dibatasi oleh strata, status sosial, tingkat pendidikan, dan suku bangsa.

Menurut pendapat Romli Atmasasmita, kekerasan jika dikaitkan dengan kejahatan, maka kekerasan sering merupakan pelengkap dari kejahatan itu sendiri. Bahkan, ia telah membentuk ciri tersendiri dalam khasanah tentang studi kejahatan. Semakin menggejala dan menyebar luas frekuensi kejahatan yang diikuti dengan kekerasan dalam masyarakat, maka semakin tebal keyakinan masyarakat akan penting dan seriusnya kejahatan semacam ini ${ }^{1}$.

Untuk mencegah, melindungi korban, dan menindak pelaku kekerasan dalam rumah tangga, negara dan masyarakat wajib melaksanakan pencegahan, perlindungan, dan penindakan pelaku sesuai dengan falsafah Pancasila dan Undang-Undang Dasar Negara RI Tahun 1945. Negara berpandangan bahwa segala bentuk kekerasan, terutama kekerasan dalam rumah tangga, adalah pelanggaran hak asasi manusia dan kejahatan terhadap

1 Atmasasmita, Romli. 2007, Teori dan Kapita Selekta Krimonologi, Rafika Aditama, hal.63 martabat kemanusiaan serta bentuk diskriminasi.

Pada tanggal 22 September 2004, telah disahkan berlakunya Undangundang Nomor 23 Tahun 2004 tentang Penghapusan Kekerasan Dalam Rumah Tangga (PKDRT), yang terdiri atas 10 Bab dan 56 Pasal. Undang-undang tersebut diharapkan dapat memberikan perlindungan hukum bagi anggota dalam rumah tangga, khususnya perempuan, yang paling banyak menjadi korban kekerasan dalam rumah tangga. Negara dan masyarakat wajib memberikan perlindungan agar setiap anggota dalam rumah tangga terhindar dari ancaman kekerasan, penyiksaan, atau perlakuan yang merendahkan derajat dan martabat manusia. Segala bentuk kekerasan harus dicegah dan dihapuskan, karena merupakan pelanggaran hak asasi manusia.

\subsection{Rumusan Masalah}

1. Apa sajakah bentukbentuk kekerasan terhadap istri dalam rumah tangga?

2. Bagaimanakah perlindungan hukum terhadap istri sebagai korban kekerasan dalam rumah tangga?

\section{B. PEMBAHASAN}

2.1 Bentuk-bentuk kekerasan terhadap istri dalam rumah tangga

Dengan disahkannya Undangundang Nomor 23 Tahun 2004 tentang Penghapusan Kekerasan Dalam Rumah Tangga, tidak berarti bahwa perjuangan perempuan sudah selesai, karena sebetulnya perjuangan perempuan masih panjang. Masih perlu dicermati, diikuti dan diawasi, sejauh mana komitmen pemerintah dalam menjalankan kewajibannya untuk melaksanakan undang-undang tersebut. Perlu diperhatikan problema apa saja yang timbul dan bagaimana penanganan yang tepat untuk mencegah dan membebaskan anggota rumah tangga, 
khususnya perempuan dari tindak kekerasan yang terjadi.

Kasus KDRT yang terjadi sesungguhnya dapat disebut sebagai fenomena gunung es. Secara kuantitas sedikit yang terdata oleh karena faktorfaktor :

1) Persepsi mengenai kekerasan yang terjadi dalam rumah tangga harus ditutup karena merupakan masalah keluarga dan bukan masalah sosial.

2) Pemahaman yang keliru terhadap ajaran agama mengenai aturan mendidik istri, kepatuhan istri pada suami, penghormatan posisi suami sehingga terjadi persepsi bahwa laki-laki boleh menguasai perempuan.

3) Budaya bahwa istri bergantung pada suami, khususnya ekonomi.

4) Kepribadian dan kondisi psikologis suami yang tidak stabil.

5) Pernah mengalami kekerasan pada masa kanak-kanak.

6) Budaya bahwa laki-laki dianggap superior dan perempuan inferior.

7) Masih rendahnya kesadaran untuk berani melapor dikarenakan dari masyarakat sendiri yang enggan untuk melaporkan permasalahan dalam rumah tangganya, maupun dari pihak- pihak yang terkait yang kurang mensosialisasikan tentang kekerasan dalam rumah tangga.

8) Masalah budaya, Masyarakat yang patriarkis ditandai dengan pembagian kekuasaan yang sangat jelas antara laki -laki dan perempuan dimana laki -laki mendominasi perempuan. Dominasi laki - laki berhubungan dengan evaluasi positif terhadap asertivitas dan agtresivitas laki - laki, yang menyulitkan untuk mendorong dijatuhkannya tindakan hukum terhadap pelakunnya. Selain itu juga pandangan bahwa cara yang digunakan orang tua untuk memperlakukan anak-anaknya , atau cara suami memperlakukan istrinya, sepenuhnya urusan mereka sendiri dapat mempengaruhi dampak timbulnya kekerasan dalam rumah tangga ( KDRT).

9) Faktor Domestik Adanya anggapan bahwa aib keluarga jangan sampai diketahui oleh orang lain. Hal ini menyebabkan munculnya perasaan malu karena akan dianggap oleh lingkungan tidak mampu mengurus rumah tangga. Jadi rasa malu mengalahkan rasa sakit hati, masalah Domestik dalam keluarga bukan untuk diketahui oleh orang lain sehingga hal ini dapat berdampak semakin menguatkan dalam kasus KDRT.

Faktor-faktor tersebutlah yang mengakibatkan kekerasan dalam rumah tangga semakin marak terjadi.Kekerasan merupakan salah satu bentuk dari kejahatan, yang tentunya akan sangat mengganggu dan meresahkan masyarakat, seperti dikatakan oleh Bonger bahwa "Kejahatan adalah perbuatan yang sangat anti sosial, yang oleh Negara ditentang dengan sadar. ${ }^{2}$

Kekerasan dalam lingkup rumah tangga atau keluarga banyak dilakukan oleh seorang suami, Adapun bentukbentuk kekerasan yang dilakukan oleh suami terhadap istri antara lain :

\section{Kekerasan Fisik}

${ }^{2}$ Bonger, W.A.,1977, Pengantar Tentang Kriminologi, Terjemahan A. Koesnoen, Ghalia Indonesia, Hal.23 
Kekerasan fisik adalah suatu tindakan kekerasan (seperti: memukul, menendang, dan lain-lain) yang mengakibatkan luka, rasa sakit, atau cacat pada tubuh istri hingga menyebabkan kematian.

\section{Kekerasan Psikis}

Kekerasan psikis adalah suatu tindakan penyiksaan secara verbal (seperti: menghina, berkata kasar dan kotor) yang mengakibatkan menurunnya rasa percaya diri, meningkatkan rasa takut, hilangnya kemampuan untuk bertindak dan tidak berdaya. Kekerasan psikis ini, apabila sering terjadi maka dapat mengakibatkan istri semakin tergantung pada suami meskipun suaminya telah membuatnya menderita. Di sisi lain, kekerasan psikis juga dapat memicu dendam dihati istri.

\section{Kekerasan Seksual}

Kekerasan seksual adalah suatu perbuatan yang berhubungan dengan memaksa istri untuk melakukan hubungan seksual dengan cara-cara yang tidak wajar atau bahkan tidak memenuhi kebutuhan seksual istri.

\section{Kekerasan Ekonomi}

Kekerasan ekonomi adalah suatu tindakan yang membatasi istri untuk bekerja di dalam atau di luar rumah untuk menghasilkan uang dan barang, termasuk membiarkan istri yang bekerja untuk dieksploitasi, sementara si suami tidak memenuhi kebutuhan ekonomi keluarga. Sebagian suami juga tidak memberikan gajinya pada istri karena istrinya berpenghasilan, suami menyembunyikan gajinya,mengambil

harta istri, tidak memberi uang belanja yang mencukupi, atau tidak memberi uang belanja sama sekali, menuntut istri memperoleh penghasilan lebih banyak, dan tidak mengijinkan istri untuk meningkatkan karirnya.

Kurang tanggapnya lingkungan atau keluarga terdekat untuk merespon apa yang terjadi, hal ini dapat menjadi tekanan tersendiri bagi korban. Karena bisa saja korban beranggapan bahwa apa yang dialaminya bukanlah hal yang penting karena tidak direspon lingkungan, hal ini akan melemahkan keyakinan dan keberanian korban untuk keluar dari masalahnya.

Selain itu, faktor penyebab terjadinya kekerasan terhadap istri berhubungan dengan kekuasaan suami/istri dan diskriminasi gender di masyarakat. Dalam masyarakat, suami memiliki otoritas, memiliki pengaruh terhadap istri dan anggota keluarga yang lain, suami juga berperan sebagai pembuat keputusan. 
Pembedaan peran dan posisi antara suami dan istri dalam masyarakat diturunkan secara kultural pada setiap generasi. Hal ini mengakibatkan suami ditempatkan sebagai orang yang memiliki kekuasaan yang lebih tinggi daripada istri. Kekuasaan suami terhadap istri juga dipengaruhi oleh penguasaan suami dalam sistem ekonomi, hal ini mengakibatkan masyarakat memandang pekerjaan suami lebih bernilai.

Kenyataan juga menunjukkan bahwa kekerasan juga menimpa pada istri yang bekerja, karena keterlibatan istri dalam ekonomi tidak didukung oleh perubahan sistem dan kondisi sosial budaya, sehingga peran istri dalam kegiatan ekonomi masih dianggap sebagai kegiatan sampingan. ${ }^{3}$

\subsection{Perlindungan Hukum Terhadap Istri} Korban Kekerasan Dalam Rumah Tangga

Bergulirnya reformasi yang diikuti dengan demokratisasi dalam kehidupan berbangsa dan bernegara di Indonesia berdampak pada upaya penegakan hukum dan perlindungan terhadap hak asasi manusia. Bangsa Indonesia sebagai negara demokrasi menunjukkan salah satu ciri negara demokrasi adalah proteksi konstitusional atau kekuasaan negara dilaksanakan berdasarkan konstitusi (rechstaats) bukan atas kekuasaan belaka. Konstitusi kita mengatur pula tentang perlindungan hak asasi manusia. ${ }^{4}$

\footnotetext{
3 Baquandi, 2009, Kekerasan Dalam Rumah Tangga http://psikologi.or.id/mycontents/uploads/20 10/10/kdrt.pdf diakses pada tanggal 18 Januari 2012

${ }^{4}$ Atmasasmita, Romli. "Latar Belakang Penyusunan RUU tentang Pengadilan HAM di Indonesia". Makalah. 18 Oktober 2000. Yogyakarta.
}

Pada asasnya, Hak Asasi Manusia menurut Bab I Pasal I angka 1 Undang-Undang Nomor 39 Tahun 1999 Tentang Hak Asasi Manusia disebutkan merupakan seperangkat hak yang melekat pada hakikat dan keberadaan manusia sebagai makhluk Tuhan Yang Maha Esa dan merupakan anugerahNya yang wajib dihormati, dijunjung tinggi dan dilindungi oleh negara, hukum dan Pemerintah, dan setiap orang demi kehormatan serta perlindungan harkat dan martabat manusia. Oleh karena itu maka pada dasarnya menurut Paul Sieghart. 5

Undang-undang Nomor 23 Tahun 2004 tentang Penghapusan Kekerasan Dalam Rumah Tangga memberikan perlindungan secara khusus bagi korban kekerasan yang terjadi dalam lingkup rumah tangga, dan dilaksanakan berdasarkan asas penghormatan hak asasi manusia, keadilan dan kesetaraan gender, non diskriminasi dan perlindungan korban, serta mempunyai tujuan untuk mencegah segala bentuk kekerasan dalam rumah tangga, melindungi korban dan menindak pelaku kekerasan dalam rumah tangga serta memelihara keutuhan rumah tangga yang harmonis dan sejahtera.

Konsepsi kekerasan sebagai kejahatan dalam konteks kehidupan berumah tangga, sebagaimana yang dikonsepsikan dalam Undang-Undang Nomor 23 Tahun 2004 tentang Penghapusan Kekerasan Dalam Rumah Tangga selanjutnya disebut UU PKDRT, adalah sebagai berikut:

"Kekerasan dalam Rumah Tangga adalah setiap perbuatan terhadap seseorang terutama perempuan, yang berakibat timbulnya kesengsaraan

${ }^{5}$ Paul Sieghart, 1986, The Lawful Rights Of Mankind, An Introduction To The International Legal Code Of Human Rights, Oxford University Press, hal.107 
atau penderitaan secara fisik, seksual, psikologis, dan/atau penelantaran rumah tangga termasuk ancaman untuk melakukan perbuatan, pemaksaan, atau perampasan kemerdekaan secara melawan hukum dalam lingkup rumah tangga".

Disahkannya Undang-undang tersebut merupakan titik awal keberhasilan perjuangan perempuan dalam memperoleh perlindungan terhadap kekerasan yang sering terjadi dalam lingkup rumah tangga, yang sebelumnya dianggap sebagai urusan pribadi suami-isteri, merupakan 'aib keluarga', tabu untuk diketahui dan dikemukakan kepada masyarakat. Ketidakberdayaan perempuan yang disebabkan adanya keinginan untuk mempertahankan posisi diri sebagai perempuan baik-baik dari keluarga yang terhormat, mengakibatkan perempuan harus bersikap pasif dan mau menerima perlakuan apapun yang diperolehnya demi mempertahankan "citra perempuan baik-baik atau keluarga harmonis.

Hal-hal demikian ini yang menyebabkan adanya kasus-kasus kekerasan dalam rumah tangga tidak terungkap dan tidak dapat diatasi. Dengan disahkannya Undang-undang Nomor 23 Tahun 2004 tentang PKDRT, tidak berarti bahwa perjuangan perempuan sudah selesai, karena sebetulnya perjuangan perempuan masih panjang.

Menurut Sudarto, Suatu kebijakan penanggulangan kejahatan apabila menggunakan upaya penal, maka penggunaanya sebaiknya dilakukan dengan lebih hati-hati, cermat, hemat, selektif, dan limitative. Penyusunan suatu perundang-undangan yang mencantumkan ketentuan pidana haruslah memperhatikan beberapa pertimbangan kebijakan sebagai berikut

1. Penggunaan hukum pidana harus memperhatikan tujuan pembangunan nasional, yaitu mewujudkan masyarakat adil dan makmur yang merata materiil spiritual berdasarkan

Pancasila; sehubungan dengan ini maka (penggunaan) hukum pidana bertujuan untuk menanggulangi

kejahatan dan mengadakan pengugeran terhadap tindakan penanggulangan itu sendiri, demi kesejahteraan dan pengayoman masyarakat.

2. Perbuatan yang diusahakan untuk dicegah atau ditanggulangi dengan hukum pidana harus merupakan perbuatan yang tidak dikehendaki, yaitu perbuatan yang mendatangkan kerugian (materiil dan atau spiritual) atas masyarakat.

3. Penggunaan hukum pidana harus memperhitungkan prinsip biaya dan hasil (cost and benefit principle) 
4. Penggunaan hukum pidana harus memperhatikan kapasitas atau kemampuan daya kerja dari badanbadan penegak hukum, yaitu jangan sampai ada kelampauan beban tugas (overbelasting) $^{6}$

Agar hukum itu berfungsi maka hukum harus memenuhi syarat berlakunya hukum sebagai kaidah yakni:

a) Kaidah hukum berlaku secara yuridis, apabila penentuannya didasarkan pada kaidah yang lebih tinggi tingkatannya atau terbentuk atas dasar yang telah ditetapkan.

b) Kaidah hukum berlaku secara sosiologis, apabila kaidah tersebut efektif. Artinya, kaidah itu dapat dipaksakan berlakunya oleh penguasa walaupun tidak diterima oleh warga masyarakat (teori kekuasaan) atau kaidah itu berlaku karena adanya pengakuan dari masyarakat.

c) Kaidah hukum berlaku secara filosofis, yaitu sesuai dengan cita hukum sebagai nilai positif yang tertinggi. ${ }^{7}$

Sebagai suatu persoalan sosial yang menuntut penyelesaian, maka upaya untuk penanggulangan kejahatan telah dimulai terus-menerus. Salah satu usaha pencegahan dan pengendalian kejahatan itu ialah menggunakan hukum pidana dengan sanksinya yang berupa

${ }^{6}$ Sudarto, 1981, Hukum dan Hukum

Pidana, Bandung, hal. 44-48

7 H. Zainuddin Ali, 2010, Filsafat Hukum, Sinar Grafika, Jakarta, hal. 94. pidana. Namun demikian usaha inipun masih sering dipersoalkan.

Sebagaimana yang dikemukakan oleh Muladi dan Barda Nawawi Arief, bahwa ada tiga alasan mengenai perlunya pidana dan hukum pidana dalam penanggulangan kejahatan yang pada intinya sebagai berikut :

a. Perlu tidaknya hukum pidana tidak terletak pada persoalan tujuan-tujuan yang hendak dicapai, tetapi terletak pada persoalan seberapa jauh untukmencapai tujuan itu boleh menggunakan paksaan, persoalannya bukan terletak pada hasil yang akan dicapai, tetapi dalam pertimbangan antara nilai dari hasil itu dan nilai dari batas-batas kebebasan pribadi masing-masing.

b. Ada usaha-usaha perbaikan perawatan yang tidak mempunyai arti sama sekali bagi si terhukum dan disamping itu harus tetap ada suatu reaksi atas pelanggaran-pelanggaran norma yang telah dilakukannya itu dan tidaklah dapat dibiarkan begitu saja.

c. Pengaruh pidana atas hukum pidana bukan semata-mata ditujukan pada si penjahat, tetapi juga untuk mempengaruhi orang yang tidak jahat yaitu warga masyarakat yang mentaati norma-norma masyarakat. ${ }^{8}$

Kebijakan penegakan hukum pidana merupakan serangkaian proses yang terdiri dari tiga tahap kebijakan yaitu :

${ }^{8}$ Barda Nawawi Arief, 2001, Masalah Penegakan Hukum dan Kebijakan Penanggulangan Kejahatan, PT Citra Aditya Bhakti Bandung,hal 152-153 
a. Tahap kebijakan legislatif (formulatif) yaitu menetapkan atau merumuskan perbuatan apa yang dapat dipidana dan sanksi apa yang dapat dikenakan oleh badan pembuat undang-undang.

b. Tahap kebijakan yudikatif/ aplikatif yaitu menerapkan hukum pidana oleh aparat penegak hukum, mulai dari kepolisian, kejaksaan, dan pengadilan.

c. Tahap kebijakan eksekutif/administratif yaitu melaksanakan hukum pidana secara konkrit, oleh aparat pelaksana pidana. ${ }^{9}$

Dihubungkan dengan faktor-faktor yang mempengaruhi pelaksanaan hukum, menurut Lawrence friedman, hukum dilihat sebagai suatu sistem hukum yang utuh, yang terdiri dari 3 komponen, yaitu:

a. Komponen substansi hukum, yang terdiri dari hasil aktual yang diberikan oleh sistem hukum, misalnya norma-norma peraturan dan sebagainya.

b. Komponen struktur hukum, yaitu kelembagaan yang diciptakan oleh sistim hukum dengan berbagai macam fungsinya dalam rangka mendukung bekerjanya hukum.

c. Komponen kultur atau budaya hukum, yaitu nilainilai yang merupakan kaidah yang mengikat sistim serta menentukan sistim

${ }^{9}$ Barda Nawawi Arief, 1998 Beberapa Aspek Kebijakan Penegakan dan Pengembangan Hukum Pidana. PL Citra Aditya Bakti Bandung, , hal.30 hukum itu di tengah kultur bangsa secara keseluruhan. ${ }^{10}$

Bagi masyarakat Indonesia, lemah kuatnya penegakan hukum oleh aparat akan menentukan persepsi ada tidaknya hukum. Bila penegakan hukum lemah, masyarakat akan mempersepsikan hukum tidak ada dan seolah-olah mereka berada dalam hutan rimba, sebaliknya, bila penegakan hukum kuat dan dilakukan secara konsisten, barulah masyarakat mempersepsikan hukum ada dan akan tunduk. Oleh karenanya penegak hukum yang tegas dan berwibawa dalam kehidupan hukum masyarakat sangat diperlukan. Patuh hukum bukanlah tataran tertinggi, melainkan adalah setiap individu dalam masyarakat yang bersikap di bawah alam sadar sesuai dengan tujuan. Kultur hukum di sini berkaitan dengan sikap sosial dan nilainilai sosial yang telah terpatri yang dipergunakan sebagai acuan normatif dalam perilaku.

Korban kekerasan dalam rumah tangga berhak mendapatkan perlindungan dari pihak keluarga, kepolisian, kejaksaan, pengadilan, advokat, lembaga sosial atau pihak lain baik sementara maupun berdasarkan penetapan perintah perlindungan dari pengadilan. Selain itu korban juga berhak memperoleh pelayanan kesehatan sesuai dengan kebutuhan medis, penanganan secara khusus berkaitan dengan kerahasiaan korban, pendampingan oleh pekerja sosial dan bantuan hukum, pada setiap tingkat proses pemeriksaan sesuai dengan ketentuan peraturan perundangundangan dan pelayanan bimbingan rohani (Pasal 10 UU. No. 23 Tahun 2004).

Korban kekerasan dalam rumah tangga juga berhak untuk mendapatkan

${ }^{10}$ Satjipto Raharjo. 1986. Hukum dan Masyarakat. Bandung: PT. Angkasa. 
pelayanan demi pemulihan dari tenaga kesehatan, pekerja sosial, relawan pendamping, dan/ atau pembimbing rohani (Ketentuan Pasal 39 UU. No.23 Tahun 2004).

Pemerintah mempunyai kewajiban dan tanggungjawab dalam upaya pencegahan kekerasan dalam rumah tangga (Ketentuan Pasal 12 UU. No.23 Tahun 2004). Sedangkan masyarakat berkewajiban melakukan upaya-upaya sesuai batas kemampuannya untuk mencegah berlangsungnya tindak pidana, memberikan perlindungan kepada korban, memberikan pertolongan darurat dan membantu proses pengajuan permohonan penetapan perlindungan Korban kekerasan dalam rumah tangga, selain memperoleh perlindungan secara fisik dan psikis dari pemerintah dan masyarakat, korban juga memperoleh perlindungan hukum, dengan pemberian sanksi pidana bagi pelaku kekerasan dalam rumah tangga, yang diatur dalam ketentuan Pasal 44 sampai dengan Pasal 53 UU. No. 23 Tahun 2004, dengan ancaman sanksi pidana yang berlainan, tergantung perbuatan yang dilakukan, dengan ancaman sanksi paling berat yaitu pidana penjara selama 20 (dua puluh) tahun atau denda Rp. 500.000.000,(Lima ratus juta rupiah), dan paling ringan 4 (empat) bulan penjara atau denda Rp.5.000.000(Lima juta rupiah).

Peran aparat penegak hukum, yaitu kepolisian, advokat dan pengadilan, dalam memberikan perlindungan dan pelayanan kepada korban kekerasan dalam rumah tangga, diatur secara khusus oleh Undangundang Nomor 23 Tahun 2004 tentang PKDRT, sebagai berikut:

- Kepolisian

Diatur dalam ketentuan Pasal 16

UU. No. 23 Tahun 2004 .Pada waktu kepolisian menerima laporan kekerasan dalam rumah tangga, harus segera dijelaskan kepada korban bahwa mereka mendapatkan pelayanan dan pendampingan. Kepolisian memperkenalkan identitas mereka dan segera wajib melakukan penyelidikan serta wajib melindungi korban. Selanjutnya kepolisian akan meminta surat penetapan perintah perlindungan dari pengadilan. Kepolisian dapat melakukan penangkapan dan penahanan terhadap pelaku.

- Advokat

Diatur dalam ketentuan Pasal 25 UU. No. 23 Tahun 2004. Di dalam memberikan perlindungan dan pelayanan, advokat wajib memberikan konsultasi hukum mengenai hak-hak korban dan proses peradilan. Mendampingi korban pada penyidikan dan pemeriksaan di dalam sidang, serta melakukan koordinasi dengan sesame penegak hukum, relawan pendamping, dan pekerja sosial agar proses peradilan berjalan sebagaimana mestinya.

- Pengadilan

Diatur dalam ketentuan Pasal 28 sampai dengan 34, 37 dan 38 UU. No. 23 Tahun 2004. Pengadilan harus mengeluarkan surat penetapan perintah perlindungan bagi korban dan anggota keluarga lain yang diajukan oleh kepolisian.

\section{PENUTUP}

Berdasarkan latar belakang permasalahan dan pembahasan seperti yang telah diuraikan diatas, maka dapat diambil suatu kesimpulan dan saran sebagai berikut:

\section{$\underline{\text { 4.1.Kesimpulan }}$}

1. Bentuk-bentuk kekerasan yang dilakukan oleh suami terhadap istri antara lain :

1. Kekerasan Fisik

Kekerasan fisik adalah suatu tindakan kekerasan (seperti: 
memukul, menendang, dan lainlain) yang mengakibatkan luka, rasa sakit, atau cacat pada tubuh istri hingga menyebabkan kematian.

2. Kekerasan Psikis

Kekerasan psikis adalah suatu tindakan penyiksaan secara verbal (seperti: menghina, berkata kasar dan kotor) yang mengakibatkan menurunnya rasa percaya diri, meningkatkan rasa takut, hilangnya kemampuan untuk bertindak dan tidak berdaya. Kekerasan psikis ini, apabila sering terjadi maka dapat mengakibatkan istri semakin tergantung pada suami meskipun suaminya telah membuatnya menderita. Di sisi lain, kekerasan psikis juga dapat memicu dendam dihati istri.

\section{Kekerasan Seksual}

Kekerasan seksual adalah suatu perbuatan yang berhubungan dengan memaksa istri untuk melakukan hubungan seksual dengan cara-cara yang tidak wajar atau bahkan tidak memenuhi kebutuhan seksual istri.

\section{Kekerasan Ekonomi}

Kekerasan ekonomi adalah suatu tindakan yang membatasi istri untuk bekerja di dalam atau di luar rumah untuk menghasilkan uang dan barang, termasuk membiarkan istri yang bekerja untuk di-eksploitasi, sementara si suami tidak memenuhi kebutuhan ekonomi keluarga. Sebagian suami juga tidak memberikan gajinya pada istri karena istrinya berpenghasilan, suami menyembunyikan

gajinya,mengambil harta istri, tidak memberi uang belanja yang mencukupi, atau tidak

$$
\begin{aligned}
& \text { memberi uang belanja sama } \\
& \text { sekali, menuntut istri } \\
& \text { memperoleh penghasilan lebih } \\
& \text { banyak, dan tidak mengijinkan } \\
& \text { istri untuk meningkatkan } \\
& \text { karirnya. }
\end{aligned}
$$

2. Perlindungan terhadap istri sebagai Korban kekerasan dalam rumah tangga berhak mendapatkan perlindungan dari pihak keluarga, kepolisian, kejaksaan, pengadilan, advokat, lembaga sosial atau pihak lain baik sementara maupun berdasarkan penetapan perintah perlindungan dari pengadilan dimana sudah diatur didalam UU. No. 23 Tahun 2004 Tentang Penghapusan Kekerasan Dalam Rumah Tangga.

\subsection{Saran}

1. Peningkatan pendidikan bagi perempuan sehingga mereka menyadari hak-hak dan kewajibannya sebagai warga negara dan warga masyarakat. Serta peningkatan kesempatan kerja dan lapangan kerja bagi perempuan, sehingga secara ekonomi tidak tergantung sepenuhnya kepada suami/laki-laki.

2. Sosialisasi peraturan perundang-undangan yang memberikan perlindungan kepada istri khususnya sosialisasi Undang-undang Nomor 23 Tahun 2004 tentang Penghapusan Kekerasan Dalam Rumah Tangga lengkap dengan peran dan fungsi Ruang Pelayanan Khusus (RPK). Memberikan advokasi dan pendampingan bagi korban serta Memberikan advokasi kebijakan pemerintah di dalam menyusun peraturan- 
peraturan yang melindungi istri.

5. Daftar Pustaka

Buku :

Barda Nawawi Arief, 1998, Beberapa Aspek Kebiiakan Penegakan dan Pengembanqan Hukum Pidana. PL Citra Aditya Bakti, Bandung. Penegakan Hukum dan Kebijakan Penanggulangan Kejahatan, PT Citra Aditya Bhakti, Bandung.

Bonger, W.A.1977. Pengantar Tentang Kriminologi, Terjemahan A. Koesnoen, Ghalia Indonesia.

H. Zainuddin Ali, 2010, Filsafat Hukum, Sinar Grafika, Jakarta.
Paul Sieghart, 1986, The Lawful Rights

Of Mankind, An Introduction To

The

International

Legal

Code Of Human

Rights, Oxford

University

Press

Romli Atmasasmita, 2007, Teori dan Kapita Selekta Krimonologi, Rafika Aditama

Satjipto Raharjo, 1986, Hukum dan Masyarakat, PT. Angkasa, Bandung. Sudarto, 1981, Hukum dan Hukum

Pidana, Bandung

$\underline{\text { Makalah }}$

Romli Atmasasmita, "Latar Belakang Penyusunan RUU tentang Pengadilan HAM di Indonesia". Makalah Yogyakarta.18 Oktober 2000. 